\title{
11
}

\section{Modeling Low Impact Development Alternatives with SWMM}

\section{Lewis A. Rossman}

The U.S. Environmental Protection Agency's Office of Water is actively promoting the use of low impact development (LID) practices to help protect and restore water quality in urban and developing areas. Such practices support the concepts of green infrastructure and sustainability by managing stormwater close to its source so as to mimic a site's predevelopment hydrology. Computational tools are needed to objectively evaluate the hydrologic benefits of proposed LID controls. The Storm Water Management Model (SWMM) is one such tool that provides an attractive framework for modeling the long term performance of LID controls. However the latest version of SWMM (Rossman, 2008) has only a limited capability to rigorously model LID alternatives (Huber et al., 2006).

This chapter describes how SWMM's runoff engine and graphical user interface were extended to explicitly model specific types of LID controls, such as permeable pavement, bio-retention areas (e.g., rain gardens and street planters), rain barrels, infiltration trenches, and vegetative swales (see Figure 11.1). Each of these controls is represented as a unique LID object with its own set of properties. These objects can be placed within standard SWMM subcatchment areas in replicate fashion. Or they can occupy their own unique subcatchments that can be linked together to form a cascading sequence of LID controls. Timedependent water balance models are used to describe the hydrologic performance of each individual LID unit. Several examples are used to illustrate how this approach was implemented within SWMM 5.

Rossman, L.A. 2010. "Modeling Low Impact Development Alternatives with SWMM." Journal of Water Management Modeling R236-11. doi: 10.14796/JWMM.R236-11.

(C) CHI 2010 www.chijournal.org ISSN: 2292-6062 (Formerly in Dynamic Modeling of Urban Water Systems. ISBN: 978-0-9808853-3-0) 

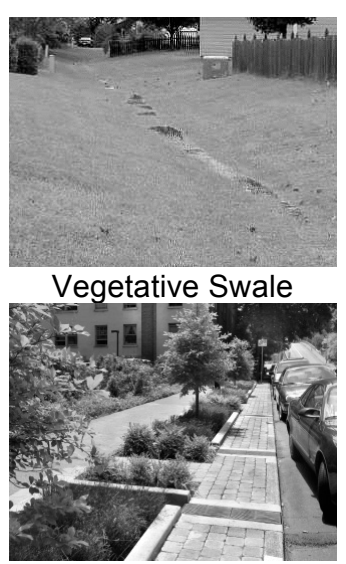

Street Planter
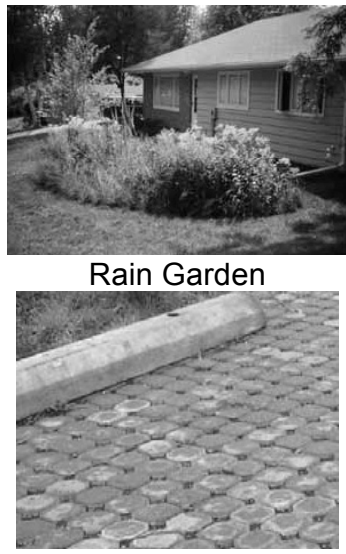

Permeable Pavement

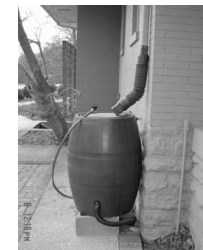

Rain Barrel

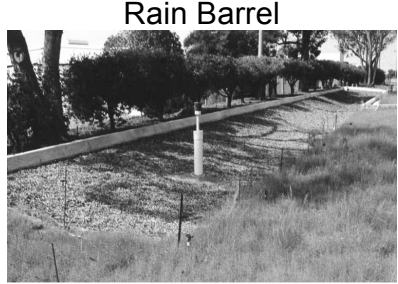

Infiltration Trench

Figure 11.1 Examples of low impact development units.

\subsection{Generic LID Model}

\subsubsection{Governing Equations}

A typical bio-retention cell (see Figure 11.2) will serve as an example for developing a generic LID performance model. This generic model can then be customized as need be to describe the behavior of the other types of LIDs pictured in Figure 11.1 above.

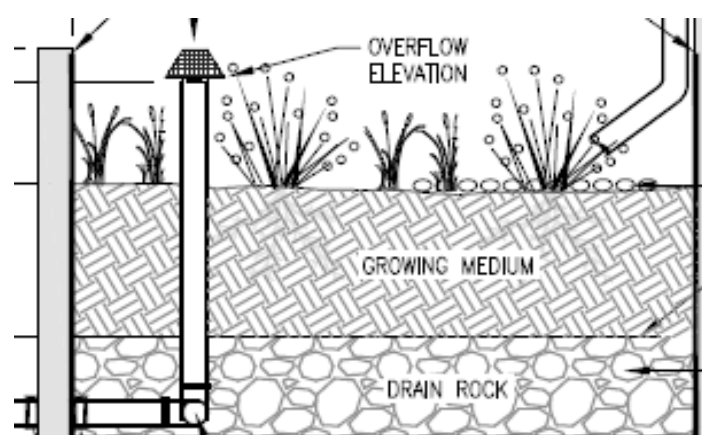

Figure 11.2 Example of a street planter bio-retention cell. 
Conceptually a generic LID unit can be represented by a number of vertical layers as shown in Figure 11.3. The surface layer receives both direct rainfall and runon from other areas. It loses water through infiltration into the soil layer below it, by evapotranspiration (ET) of any water stored in depression storage and vegetative capture, and by any surface runoff that might occur. The soil layer contains an amended soil mix that can support vegetative growth. It receives infiltration from the surface layer and loses water through ET and by percolation into the storage layer below it. The storage layer consists of coarse crushed stone or gravel. It receives percolation from the soil zone above it and loses water by either infiltration into the underlying natural soil or by outflow through a perforated pipe underdrain system.

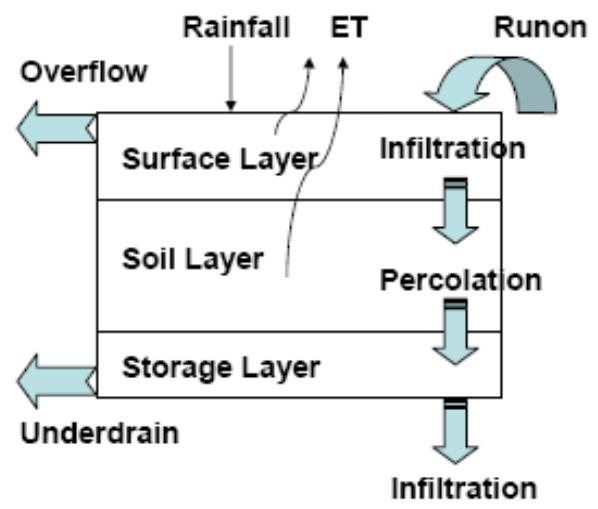

Figure 11.3 Conceptual representation of a generic LID unit.

The hydrologic performance of this LID unit can be modeled by solving simple mass balance equations that express the change in water volume in each layer over time as the difference between the inflow water flux rate and the outflow flux rate. These equations for the surface layer (Equation 11.1), the soil layer (Equation 11.2), and the storage layer (Equation 11.3) can be written as:

$$
\begin{aligned}
& \frac{\partial d_{1}}{d t}=i+q_{0}-e_{1}-f_{1}-q_{1} \\
& L_{2} \frac{\partial \theta}{d t}=f_{1}-e_{2}-f_{2} \\
& \phi \frac{\partial d_{3}}{d t}=f_{2}-f_{3}-q_{1}
\end{aligned}
$$


where:

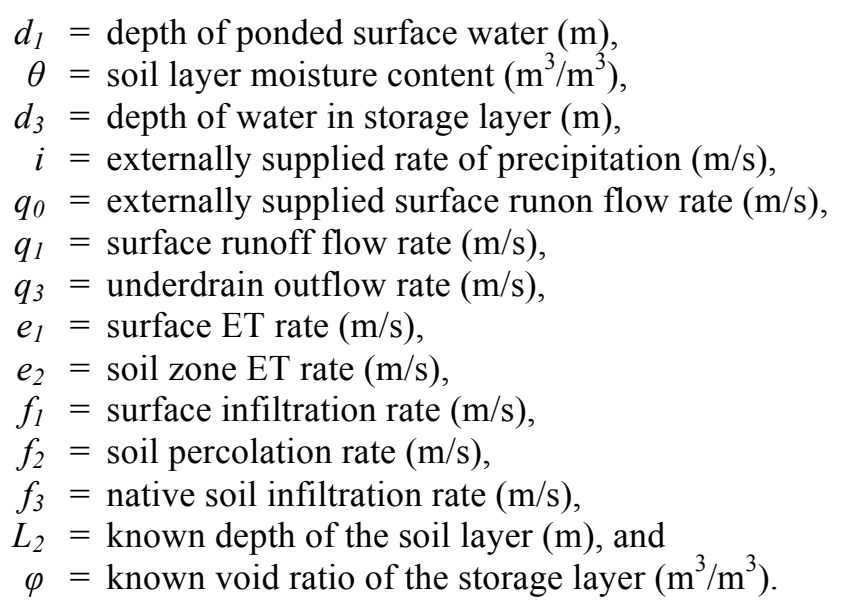

The flux terms $(q, e$, and $f)$ in these equations are functions of the current water content in the various layers $\left(d_{1}, \theta\right.$, and $\left.d_{3}\right)$ and specific site and soil characteristics. This set of equations can be solved numerically at each runoff time step to determine how an inflow hydrograph to the LID unit is converted into some combination of runoff hydrograph, sub-surface storage, sub-surface drainage, and infiltration into the surrounding native soil. As applied to a bioretention cell, this generic model is similar in spirit to the RECARGA model developed at the University of Wisconsin-Madison (Atchison and Severson, 2004).

\subsubsection{Flux Terms}

This section describes how the various flux terms that appear in Equations 11.1-11.3 can be represented. All of these terms can be evaluated with equations that already appear in one form or another in SWMM, so no new modeling constructs are required for this purpose.

Direct precipitation and runon can infiltrate into the upper soil layer $\left(f_{l}\right)$. Similarly, water stored in the bottom storage layer can infiltrate into the native soil $\left(f_{3}\right)$ if the unit does not have an impermeable bottom liner. The most convenient way to model this infiltration is with the Green-Ampt equation:

$$
f=K_{s}\left(1+\frac{\left(\phi-\theta_{0}\right)(d+\psi)}{F}\right)
$$


where:

$$
\begin{aligned}
f & =\text { infiltration rate }\left(\text { either } f_{I} \text { or } f_{3}\right)(\mathrm{m} / \mathrm{s}), \\
K_{s} & =\text { saturated hydraulic conductivity }(\mathrm{m} / \mathrm{s}), \\
\varphi & =\text { soil porosity }\left(\mathrm{m}^{3} / \mathrm{m}^{3}\right), \\
\theta_{0} & =\text { initial soil moisture content }\left(\mathrm{m}^{3} / \mathrm{m}^{3}\right), \\
d & =\text { depth of ponded water }(\mathrm{m}), \\
\psi & =\text { suction head at the wetting front }(\mathrm{m}), \text { and } \\
F & =\text { cumulative infiltration volume }(\mathrm{m}) .
\end{aligned}
$$

This equation applies only after a saturated condition develops at the top of the soil zone. The properties $K_{s}, \varphi$, and $\psi$ for the amended soil can be different from those of the site's natural soil which can produce a different infiltration rate at the unit's surface compared to that at its base.

SWMM 5 already implements this same Green-Ampt model, except that it ignores the effect of the ponded depth $d$ because it is normally negligible when considering just runoff from land surfaces. The SWMM source code has been modified to now include ponded depth in its Green-Ampt equation.

The rate of percolation of water through the soil layer into the storage layer below it, or into the native soil if no storage layer is present, $\left(f_{2}\right)$ can be modeled using Darcy's Law in a manner similar to that used in SWMM's existing groundwater module. The resulting equation for this flux is:

$$
f_{2}=K_{s} \exp (-(\phi-\theta) H C O)
$$

where:

$$
\begin{aligned}
H C O= & \text { a coefficient derived from moisture retention curve } \\
& \text { data that describes how conductivity decreases with } \\
& \text { decreasing moisture content. }
\end{aligned}
$$

The $H C O$ coefficient has the same meaning as it does when used in SWMM's groundwater module.

Evapotranspiration (ET) from the surface and soil layer proceeds in the same sequential fashion that SWMM also currently employs within its groundwater module. Starting with a user-supplied time series of daily potential ET rates $E_{0}$, evaporation from the surface is first computed as:

$$
e_{1}=\min \left(E_{0}, d_{1} / \Delta t\right)
$$

where:

$$
\Delta t=\text { computational time step (s). }
$$

Evapotranspiration exerted within the soil layer is then a user-specified frac- 
tion $e_{s}$ of the remaining potential evapotranspiration:

$$
e_{2}=\min \left(\max \left(e_{s}\left(E_{0}-e_{1}\right), 0\right), L\left(\theta-\theta_{W P}\right) / \Delta t\right)
$$

where:

$$
\theta_{W P}=\text { the soil's wilting point moisture content }\left(\mathrm{m}^{3} / \mathrm{m}^{3}\right) \text {. }
$$

This is an admittedly crude way of representing ET and should be refined in future revisions of SWMM.

Outflow from the surface layer of the LID unit $\left(q_{l}\right)$ can either be surface runoff when the unit is unconfined (as in a rain garden) or be flow through an overflow structure for a confined unit (such as a street planter). For surface runoff, the Manning equation can be used in the same fashion that SWMM currently employs it for overland surface flow:

$$
q_{1}=\frac{1.49}{n} A R^{2 / 3} S^{1 / 2}
$$

where:

$$
\begin{aligned}
n & =\text { surface roughness coefficient } \\
S & =\text { surface slope }(\mathrm{m} / \mathrm{m}) \\
A & =\text { flow area (flow width times flow depth) }\left(\mathrm{m}^{2}\right), \text { and } \\
R & =\text { hydraulic radius of the flow area }(\mathrm{m}) .
\end{aligned}
$$

Note that both $A$ and $R$ are functions of the depth of overland flow, which is the ponded depth $d_{l}$ minus any depression storage $d_{S}(\mathrm{~m})$.

Outflow through a vertical drain pipe or over a berm can be computed using the weir equation:

$$
q_{1}=C_{W} L_{W}\left(d_{1}-d_{s}\right)^{3 / 2}
$$

where:

$$
\begin{aligned}
C_{W}= & \text { weir coefficient }\left(\mathrm{m}^{2 / 3} / \mathrm{s}\right), \text { and } \\
L_{W}= & \text { drain pipe circumference or berm length }(\mathrm{m}) . \\
& \text { Note that } q_{1}=0 \text { when } d_{l}<d_{s} .
\end{aligned}
$$

Finally, because the hydraulics of underdrains can be complicated, a simple empirical power law can be used to model drainage outflow from the storage layer $\left(q_{3}\right)$ :

$$
q_{3}=C_{D}\left(d_{3}-d_{d}\right)^{\eta}
$$

where:

$$
\eta=\text { discharge exponent, }
$$




$$
\begin{aligned}
C_{D}= & \text { discharge coefficient }\left(\mathrm{m}^{(1-\eta)} / \mathrm{s}\right) \text {, and } \\
d_{d}= & \text { depth of drain opening above bottom of drainage layer } \\
& (\mathrm{m}) . \\
& \text { Note that, as with } q_{1}, q_{3}=0 \text { when } d_{3}<d_{d} .
\end{aligned}
$$

Note that these equations do not introduce any new parameters that are not already used in SWMM 5's existing sub-models for infiltration, overland flow, groundwater flow, and flow through weirs and outlets.

\subsection{Representing Specific LID Units}

Table 11.1 lists which layers and flux terms from the generic LID model developed in the previous section apply to specific types of LID controls. Note that the aforementioned generic LID unit is represented in this table by the bioretention cell.

Table 11.1 Representation of different LID units.

\begin{tabular}{lll}
\hline \multicolumn{1}{c}{ LID Unit } & Layers & \multicolumn{1}{c}{ Flux Terms ${ }^{1}$} \\
\hline Rain Barrel & Surface, & Surface Overflow, \\
& Storage & Underdrain Flow \\
Porous Pavement & Surface, & Overland Flow, \\
& Storage & Underdrain Flow / Native Soil Infiltration \\
Infiltration Trench & Surface, & Surface Overflow, \\
& Storage & Underdrain Flow / Native Soil Infiltration \\
Vegetative Swale & Surface & Overland Flow, \\
& & Native Soil Infiltration \\
Bio-retention Cell & Surface, & Overland Flow / Surface Overflow, \\
& Soil, & Soil Infiltration, Soil Percolation, \\
& Storage & Underdrain Flow / Native Soil Infiltration \\
\hline
\end{tabular}

${ }^{1}$ All units include possible evapotranspiration.

Rain barrels consist of just a surface layer that receives runon captured from a rooftop and has an overflow outlet, plus a storage zone with a $100 \%$ void ratio and an underdrain outlet whose flow coefficients are equivalent to those of an orifice.

A porous pavement LID is similar to an infiltration trench in that both contain a surface layer with a gravel-filled storage layer beneath it. Surface outflow from the porous pavement unit is computed from the overland flow equation while the weir equation would be better suited for modeling overflow that occurs over an infiltration trench's berm enclosure. Either underdrain outflow or infiltration into the native soil would apply to these LIDs depending on their design. 
The vegetative swale is modeled with just a surface layer that uses the overland flow equation for outflow along with native soil infiltration. It differs from the other LID units in that the user must also supply the dimensions of the swale's trapezoidal cross-section along with the length of its flow channel. The ponded depth value used in the Green-Ampt infiltration equation is the average distance between the water surface and the ground surface over the trapezoidal cross-section of the swale.

\subsection{SWMM Implementation}

\subsubsection{LID Objects}

SWMM 5 was modified to model LID-type best management practices (BMPs) by adding a new category of objects named BMPs to its existing collection of hydrology objects. These objects represent particular LID units of a given size and design that can be placed in replicate fashion into any number of subcatchments, in exactly the same way that aquifer objects or snow pack objects are currently used in SWMM for modeling groundwater and snow melt, respectively. The label $B M P$ rather than LID was used here because it is a more recognizable term and can refer to a larger variety of control alternatives.

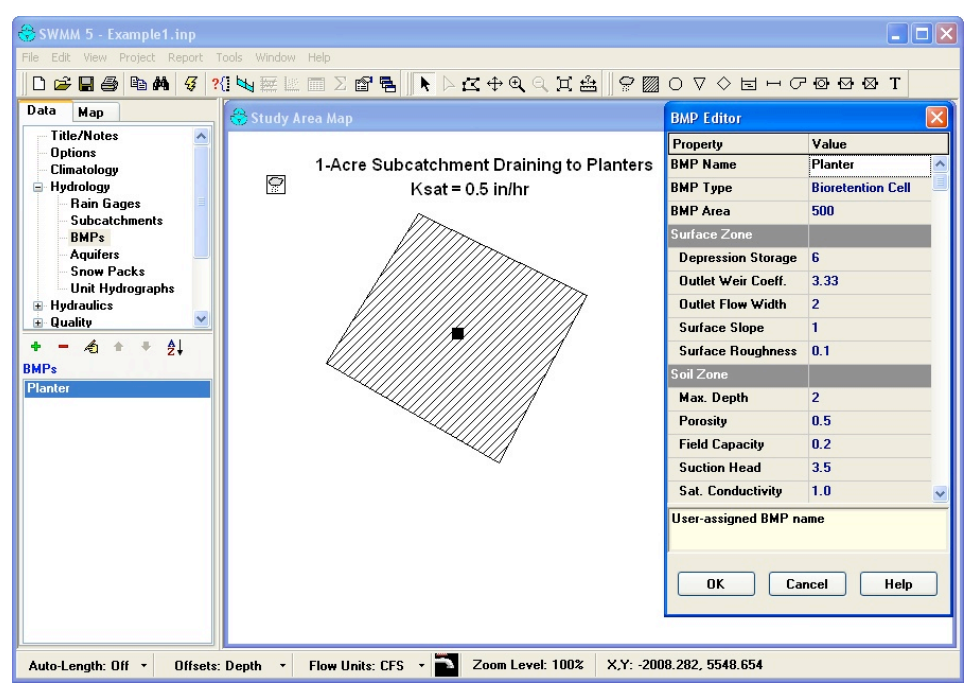

Figure 11.4 Adding a LID BMP into a SWMM project. 
Figure 11.4 above illustrates the process of adding a new LID object into a project along with the input form that is used to assign its properties. Upon choosing a specific type of LID BMP, the form displays only those data entry fields relevant to the particular LID model representation listed in Table 11.1 above.

\subsubsection{Placing LID Objects in Subcatchments}

LID objects by themselves do not serve any function until they are actually associated with a SWMM subcatchment object. The latter object is the principle hydrological unit for which rainfall-runoff response is computed in SWMM. A new property named BMP Process was added to the existing set of subcatchment properties to identify which LID BMP object should be placed within the subcatchment. Once such an assignment is made, the user can specify how many replicate units of the LID object should be placed in the subcatchment and what proportions of the runoff produced from both the pervious and impervious areas of the subcatchment receive treatment through the LID units. The total runoff to be treated is split evenly between the replicate units.

A second way to add LID units into a project is to use subcatchments that are entirely devoted to just a single LID unit. In this case the Area property of the subcatchment proper would be set to zero so that only the LID contributes any area to it. This facilitates stringing together a sequence of LID units, where the runoff from one becomes the runon to another. An example of this approach involving vegetative swales is presented later on.

\subsubsection{Computing LID Performance}

A new code module was added to the SWMM 5 computational engine to solve the flow balance equations for the various types of LID objects that the program recognizes. At each runoff time step, runoff from the non-LID portion of each subcatchment is first computed in the usual manner. Then the user's designated proportion of this runoff is directed onto any LID units contained within the subcatchment. The appropriate set of flow balance equations for the LID unit is solved over the time step to determine the volumes of water that become runoff, that infiltrate or evaporate, and that remain stored within the unit. Because these equations can be somewhat stiff, an iterative backwards difference method (similar to the modified Puls method) is used to solve them. Any runoff produced from the LID units is combined with the non-LID diverted runoff to determine the total runoff from the subcatchment in question. 


\subsection{Illustrative Examples}

Two illustrative examples, bioretention and vegetative swales, are presented which demonstrate the kinds of analyses that can be made with the LID extensions added to SWMM 5.

\subsubsection{Bio-retention Example}

In this first example a number of $500 \mathrm{ft}^{2}\left(46.5 \mathrm{~m}^{2}\right)$ street planters of the type shown in Figure 11.2 above are to be placed in a highly urbanized acre ( $0.4 \mathrm{ha})$ of area that is $90 \%$ impervious. The objective is to determine what reduction in runoff volume can be achieved as the number of planters is increased.

The first step in applying SWMM to this example is to create a BMP object (named Planter) that represents a single $500 \mathrm{ft}^{2}\left(46.5 \mathrm{~m}^{2}\right)$ bio-retention cell planter with the properties listed in Table 11.2. Next a single subcatchment is created that represents the entire 1 acre $(0.4 \mathrm{ha})$ study area. Its properties are listed in Table 11.3. The Planter BMP object is then assigned to this subcatchment's BMP Process property with the number of replicates to be varied as part of the analysis.

Table 11.2 Bio-retention cell properties.

\begin{tabular}{lc}
\hline Property & Value \\
\hline Surface Layer & $500 \mathrm{ft}^{2}$ \\
Area & $6 \mathrm{in.}$ \\
Depression Storage & $2 \mathrm{ft}$ \\
Overflow Pipe Diameter & 3.33 \\
Overflow Weir Coefficient & \\
Soil Layer & $2 \mathrm{ft}$ \\
Depth & 0.5 \\
Porosity & 0.2 \\
Field Capacity & $3.5 \mathrm{in}$. \\
Suction Head & $1.0 \mathrm{in} . / \mathrm{h}$ \\
Hydraulic Conductivity & 10 \\
Conductivity Coefficient & \\
Depth & $1 \mathrm{ft}$ \\
Void Fraction & 0.8 \\
Permeable Bottom & Yes \\
Underdrain Pipe & No \\
\hline
\end{tabular}


Table 11.3 Subcatchment properties.

\begin{tabular}{ll}
\hline \multicolumn{1}{c}{ Property } & \multicolumn{1}{c}{ Value } \\
\hline Area & $1 \mathrm{acre}$ \\
Slope & $0.5 \%$ \\
Width & $400 \mathrm{ft}$ \\
Imperviousness & $90 \%$ \\
Impervious Roughness & 0.01 \\
Pervious Roughness & 0.10 \\
Depression Storage & $0.05 \mathrm{in}$. \\
Impervious Area with No Depression Storage & $25 \%$ \\
Soil Suction Head & $3.5 \mathrm{in}$. \\
Hydraulic Conductivity & $0.5 \mathrm{in} . / \mathrm{h}$ \\
Initial Moisture Deficit & 0.26 \\
\hline
\end{tabular}

Multiple runs of this simple model were made for a $1 \mathrm{in}$. $(25.4 \mathrm{~mm}), 6 \mathrm{~h}$ design storm using a different number of planters for each run. The resulting total runoff hydrographs for 0 planters, 3 planters, and 5 planters, respectively, are shown in Figure 11.5. Note that as the number of planters increases, the delay in the onset of runoff increases while the total volume of runoff decreases. This runoff begins rather suddenly once the depth of ponded water on the surface exceeds the height of the overflow pipe.

- No Planters -3 Planters -5 Planters

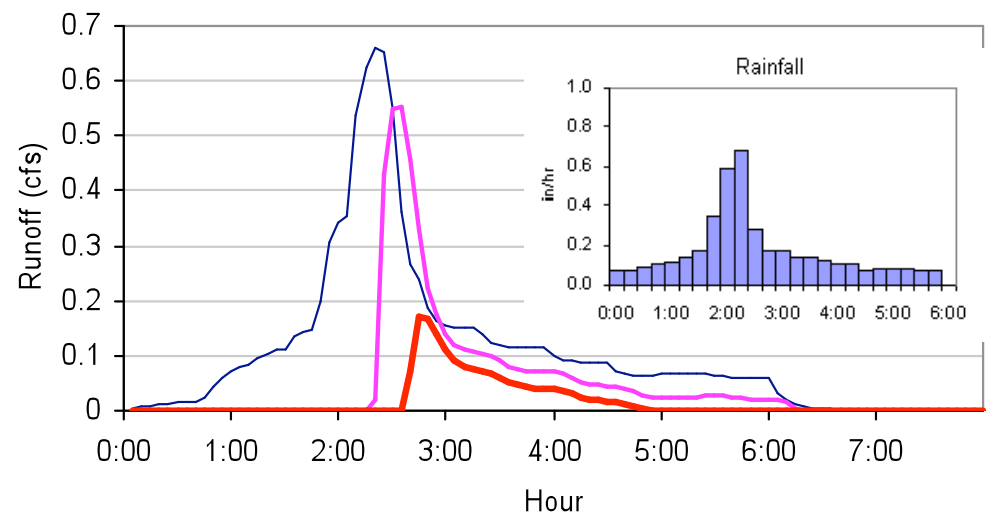

Figure 11.5 Runoff hydrographs for bio-retention example.

Table 11.4 shows what fraction of the 1 in. $(25.4 \mathrm{~mm})$ rainfall becomes runoff as the number of planter units is increased. Five planters covering only $6 \%$ 
of the total area are capable of controlling almost $90 \%$ of the rainfall volume. To show that this result is indeed feasible, consider that the total storage volume available in each planter unit is $1.9 \mathrm{ft}(0.6 \mathrm{~m})$ while the volume of runon plus rainfall to each of 5 planters from the design storm is $1.5 \mathrm{ft}(0.5 \mathrm{~m})$. It is interesting to note that the City of Portland Storm Water Management Manual recommends this same $6 \%$ value as a sizing factor for street planters (City of Portland, 2008).

Table 11.4 Runoff coefficients for bio-retention example.

\begin{tabular}{lccccccc}
\hline Number of Planters & 0 & 1 & 2 & 3 & 4 & 5 & 6 \\
\hline Runoff Coefficient & 0.84 & 0.67 & 0.52 & 0.38 & 0.25 & 0.12 & 0.01 \\
\hline
\end{tabular}

In contrast to the runoff, which only persists for a time slightly longer than the rainfall event, the water stored in the planter persists over several days' time. This extended drying time could impede performance when successive storm events occur. To assess the long term performance of the planters, a one year simulation was made using rainfall data from Raleigh, North Carolina. The resulting time histories of runoff with both no planters and five planters are shown in Figure 11.6. With no planters there were 122 days with measurable runoff. With five planters installed this number was reduced to only nine days.
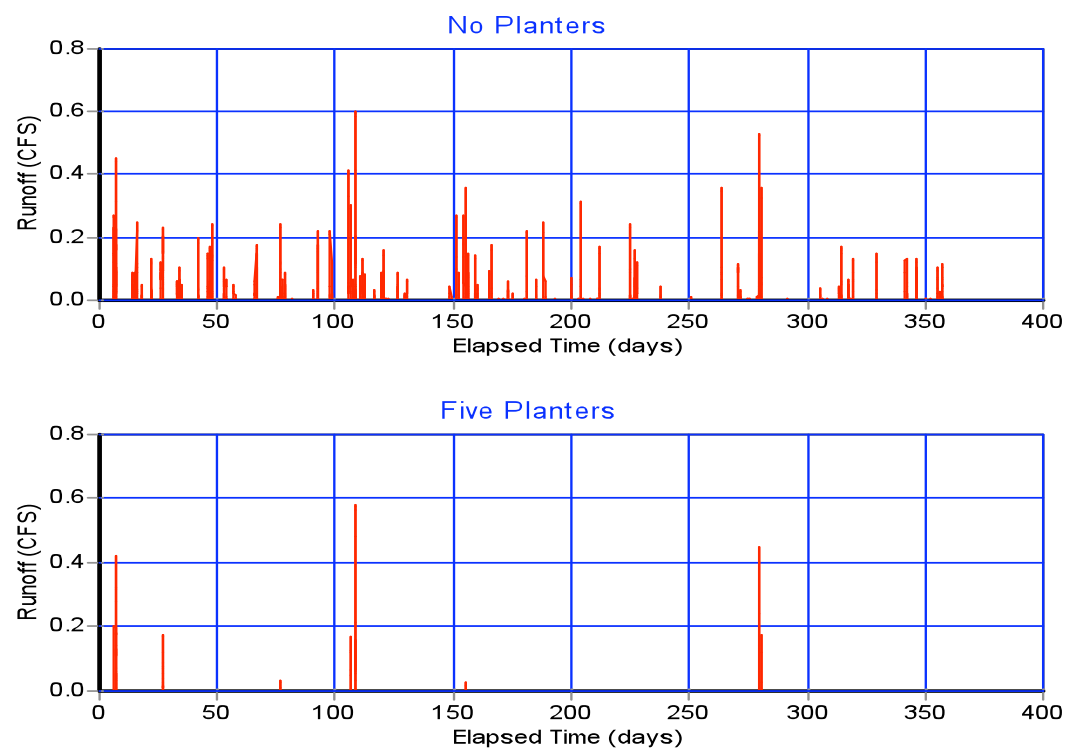

Figure 11.6 Frequency of runoff events for bio-retention example. 


\subsubsection{Vegetative Swales Example}

As a second example the effectiveness of vegetative swales in controlling runoff for a $2 \mathrm{~h} 1 \mathrm{in}$. $(25.4 \mathrm{~mm})$ design storm on a 40 acre (16.2 ha) residential site in Colorado is evaluated (see Figure 11.7). The original design used a series of dry streambed channels, modeled as conduit objects, to convey runoff through an undeveloped section of the site. An alternative is to replace them with vegetated swale LIDs of the same dimensions. Because of their dense grass cover, the roughness of the swales would be significantly higher than that of the streambed conduits, plus they provide an opportunity for infiltration.

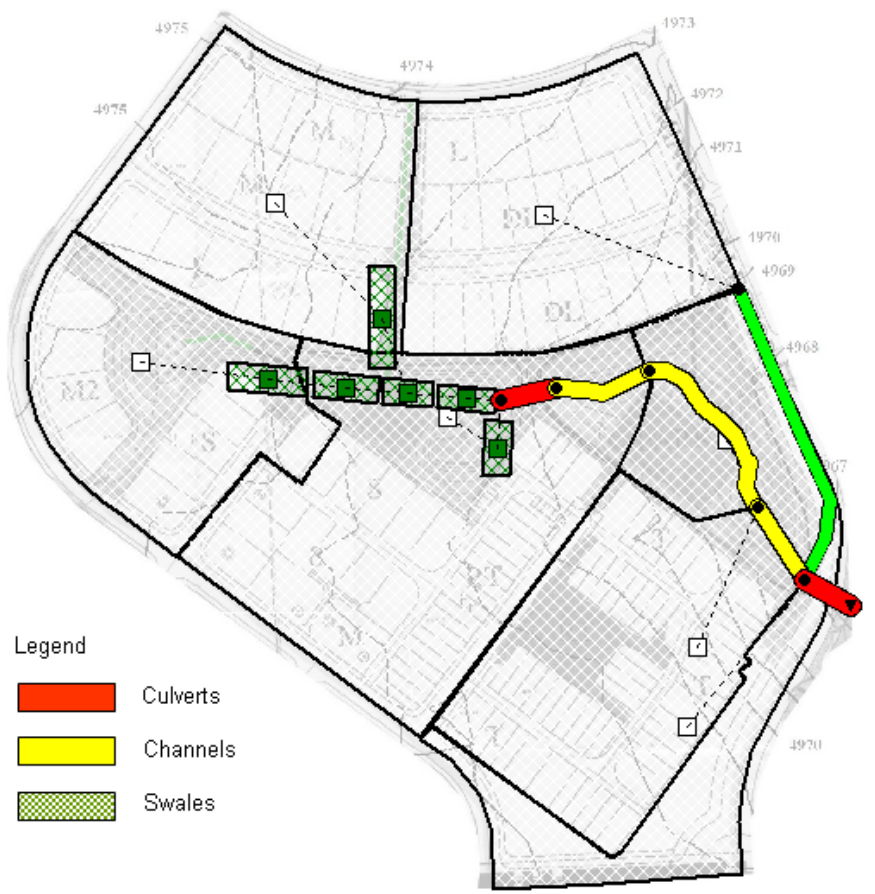

Figure 11.7 Study area for vegetative swales example (dashed lines show where runoff enters the conveyance system).

Both the swales and the streambed conduits they replaced have $5 \mathrm{ft}(1.5 \mathrm{~m})$ wide by $3 \mathrm{ft}(0.9 \mathrm{~m})$ high trapezoidal cross sections with a 5:1 side slope. The surface slopes of these channels vary but average 1.3\%. The Manning's $n$ for 
the streambeds was taken as 0.05 while a value of 0.24 was used for the swales. All soils had a saturated hydraulic conductivity of $1.0 \mathrm{in} . / \mathrm{h}(25.4 \mathrm{~mm} / \mathrm{h})$.

The swales were represented by six individual swale BMP objects within SWMM because even though each swale segment has the same cross-section and roughness, their lengths and slopes vary. Each one of these swale objects was placed within its own subcatchment that was entirely comprised of just the swale. The swale subcatchments were chained together as shown in Figure 11.7 by setting the outlet property of an upstream swale subcatchment to the appropriate downstream swale subcatchment.

Figure 11.8 compares the runoff produced out of the most downstream swale/streambed channel for the 1 in. $(25.4 \mathrm{~mm})$ design storm. Recall that the streambed channels have much lower roughness than the swales and do not allow for infiltration. The results show that the swales provide $>50 \%$ reduction in the peak flow rate along with a more moderate reduction of $11 \%$ total runoff volume relative to the original streambed design..

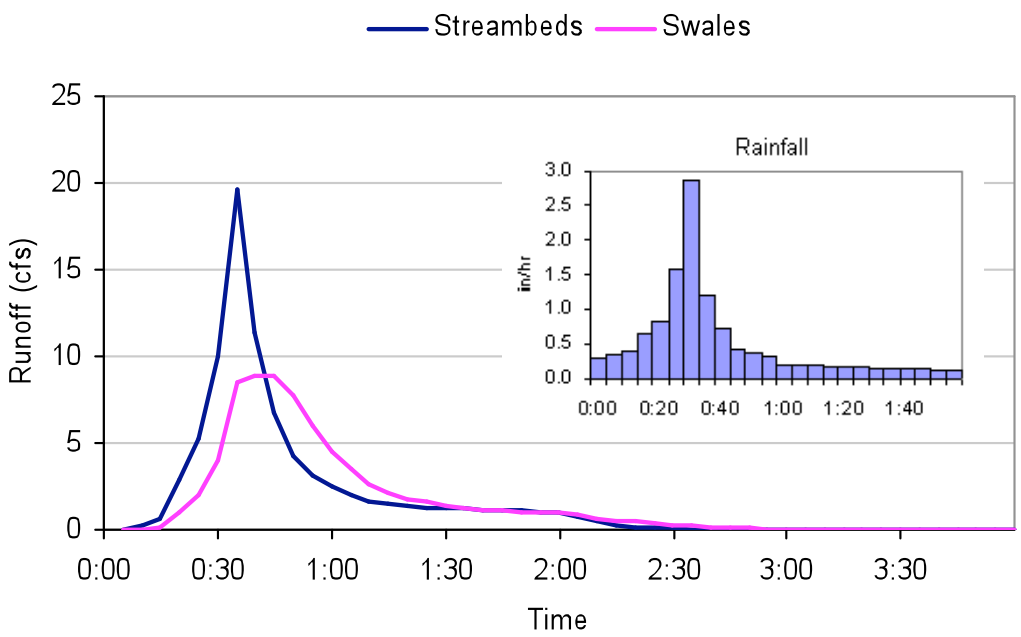

Figure 11.8 Runoff for vegetative swale example.

\subsection{Conclusions}

SWMM 5 was successfully modified to directly model several different types of LID controls. Each of these controls is represented as a unique LID object with its own set of properties. These objects can be placed within standard 
SWMM subcatchment areas in replicate fashion, or they can occupy their own unique subcatchments that can be linked together to form cascading sequences of LID controls. Time-dependent water balance models are used to describe the hydrologic performance of each type of LID unit. These models consist of some combination of surface, soil, and storage layers (depending on LID type) subjected to such hydrologic processes as infiltration, percolation, ET, overflow discharge, and overland flow.

As this was considered a first generation effort, all of the aforementioned hydrologic processes were modeled using the numerical methods already contained within SWMM. A number of enhancements to these methods should be considered for future updates. These include:

- Allowing a mix of LID controls to be placed within a subcatchment where each control can treat a different fraction of the subcatchment's total area;

- Adding vegetative canopy interception to the bio-retention and vegetative swale models (Xioa et al., 2007);

- Improved ET modeling for bio-retention that considers the effect of vegetative cover and soil moisture content on plant transpiration (Allen et al., 1998);

- Accounting for how vegetation stiffness and height along with flow velocity affects Manning's roughness for vegetative swales (Kouwen and Unny, 1973); and

- The LID-extended version of SWMM discussed in this chapter is currently undergoing further testing and validation against data collected from experimental LID installations before being released for general distribution.

\section{Acknowledgment}

The U.S. Environmental Protection Agency, through its Office of Research and Development, funded and managed, or partially funded and collaborated in, the research described herein. It has been subjected to the Agency's peer and administrative review and has been approved for external publication. Any opinions expressed are those of the author and do not necessarily reflect the views of the Agency; therefore, no official endorsement should be inferred. Any mention of trade names or commercial products does not constitute endorsement or recommendation for use. 


\section{References}

Allen R.G., Pereira, L.S., Raes, D., and Smith, M. (1998). Crop EvapotranspirationGuidelines for Computing Crop Water Requirements. FAO Irrigation and Drainage Paper 56. Food and Agricultural Organization of the United Nations, Rome, Italy.

Atchison, D. and Severson, L. (2004). RECARGA User's Manual. University of Wisconsin-Madison, Civil and Environmental Engineering Department (available at http://dnr.wi.gov/runoff/stormwater/technote.htm).

City of Portland. (2008). "Stormwater Management Model—Chapter 2: Facility Design." Revision 4. (http://www.portlandonline.com/bes/index.cfm?c=47954\&a=202883).

Huber, W. C., Cannon, L. and Stouder, M. (2006). BMP Modeling Concepts and Simulation, EPA/600/R-06/033, U.S. Environmental Protection Agency, Edison, NJ.

Kouwen, N. and Unny, T. E. (1973). "Flexible Roughness in Open Channels." Journal of the Hydraulic Division, Proceedings of ACSE, 99(HY5), 713-728.

Rossman, L.A. (2008). Storm Water Management Model User's Manual Version 5.0, EPA/600/R-05/040, U.S. Environmental Protection Agency, Cincinnati, OH.

Xiao, Q., McPherson, E.G., Simpson, J.R., and Ustin, S.L. (2007). "Hydrologic processes at the urban residential scale." Hydrol. Process., 21, 2174-88. 